

\section{Role of Career Oriented Perceived Organizational Support in Determining Subjective Career Success of Supervisory Level Managers in Manufacturing Firms}

\author{
Widana Pathiranage Richard \\ Wickramaratne
}

\section{Introduction}

Changes in the socio-economic environment over the past few decades have noticeably influenced the concept of career in relation to career management. The contemporary concept of career is different from the traditional concept, in that the responsibility for managing careers has shifted from the employer to the employee and to a greater focus on career selfmanagement (Arthur et al., 2005; De Vos et al., 2009; Stickland, 1996; Sullivan, 1999). In spite of the growing importance of career self-management, organizational career management still remains an integral responsibility of firms, since it forms the context in which career development takes place (Baruch, 1999; Eby, Allen, \& Brinley, 2005).

To date, there is no single conceptualisation of what constitutes organizational support for career development. Varied conceptualisations have been used depending on the purposes and outcomes of interest in particular studies, making the implementation of supportcentred practices non-uniform (Bambacas \& Bordia, 2009; Barnett \& Bradley, 2007; Ng et al., 2005; Orpen, 1994; Dubin, 1977; Kaufman, 1974; Kozlowski \& Hults, 1987). Among various conceptualizations for career support, vast majority of studies have operationalized organisational support as general organizational support and used the organizational support scale developed by Eisenberger et al. (1986). These studies have revealed that the perceived organizational support influences affective outcomes and career satisfaction perceptions. However, Kraimer, Seibert, Wayne, Liden, \& Bravo (2011) argued that the use of a general organizational support measure to report on career-related organisational support may not be sufficiently fine grained. In a review of more than 70 studies, Rhoades and Eisenberger (2002) and a review of 558 studies by Kurtessi and Eisenberger (2017) reported that no studies specifically addressed how career related perceived organizational support relates to subjective career success of employees.

Therefore, the aim of this study was to determine whether career oriented perceived organizational support is related to the subjective career success of employees. Thus, the purpose of this study was to investigate whether the career oriented perceived organizational support is positively associated with subjective career satisfaction of employees. By addressing the overarching problem, the current study has made three main significant contributions. First, a new scale for career oriented perceived organizational support (POS-Career) was developed and validated. Second, a significant contribution was made to the career development literature by conducting this study in a developing country context since only a scant amount of literature is available in this area of interest. Finally, this study has made implications to the theories such as social exchange (Blau, 1964), psychological contract (Argyris, 1960; Rousseau, 1989), perceived organizational support (Eisenberger et al.,1986) and the extended model of social cognitive career theory (Lent and Brown, 2006).

\section{Literature Review}

Much of the research in this area is based on the premise of psychological contract and social exchange theories. The psychological contract introduced by Argyris (1960) suggests that the employment relationship goes beyond the formal economic employment contract. The psychological contract is defined by Rousseau (1990, p.390) as “an individual's beliefs regarding reciprocal obligations set in the context of the employer/employee relationship." The psychological contract emerges when the employee believes that "a promise has been made and a consideration offered in exchange for it, binding the parties to some set of reciprocal obligations" (Rousseau 1989, p. 123). As explained by Blau (1964), social exchanges involve unspecified obligations: when one person does another a favour, there is an expectation of some future return. Employees tend to take a long-term approach to social exchange relationships at work, with the pattern of reciprocity over time determining the perceived balance in exchanges (Blau, 1964; Rousseau 1989).

Psychological mechanisms explain the potential consequences of perceived organisational support. Based on the reciprocity norm, perceived organisational support produces a felt obligation in individuals to care about the organisation's welfare and to help the organisation reach its objectives (Eisenberger et al., 1986). The caring, approval, and respect connoted by perceived organizational support fulfils socio-emotional needs, leading individuals to incorporate organisational membership and role status into their social identity. Perceived organisational support strengthens employee beliefs that the organisation recognises, and rewards increased performance, thereby reinforcing performancereward expectancies. Together, these psychological processes result in favourable outcomes for both employees (i.e. increased job satisfaction, and heightened positive mood) and the organisation (i.e. increased affective commitment and performance; reduced turnover) (Ahmed et al., 2015; Rhoades \& Eisenberger, 2002).

One way that career success was operationalized by previous researchers was based on the variables that measure subjective or intrinsic career success (e.g., Judge et al., 1995). Such variables capture individuals' subjective judgments about their career attainments, such as job and career satisfaction (e.g., Burke, 2001; Judge et al., 1999). Prior studies have interchangeably used the 
terms subjective career success and subjective career satisfaction to define the employees' belief about their career progress is consistent with their own goals, values and preferences (Erdogan et al., 2004; Heslin, 2003; Seibert \& Kraimer, 2001).

According to the predictions of the extended model of social cognitive career theory (Lent \& Brown, 2006), goal-specific environmental support, such as POSCareer, which provides for social support in achieving employee personal goals, is likely to be a predictor of career satisfaction. When employees perceive that the management of the firm is unsupportive, employees appear to view their jobs as displeasing and experience job dissatisfaction (Susskind, Borchgrevink, Kacmar, \& Brymer, 2000). Such employee perceptions demonstrate that the organisation does not care about employee wellbeing and does not provide adequate support, whenever needed, to carry out job related tasks effectively (Rhoades \& Eisenberger, 2002). Therefore, empirical studies suggest that perceived organisational support is a strong predictor of career satisfaction because it facilitates the achievement of individual career goals (Allen et al., 2003; Armstrong-Stassen \& Ursel, 2009; Cable \& DeRue, 2002; Erdogan et al., 2004; Karatepe, 2012).

From data gathered from frontline hotel employees and their immediate supervisors in Turkey, Karatepe (2012) found that perceived organizational support is positively related to the career satisfaction of employees. This study employed the career satisfaction scale of Greenhaus et al. (1990) to measure the career satisfaction of employees. Armstrong-Stassen \& Ursel (2009) conducted two surveys in Canada, first of which consisted of 239 managerial and professional employees while the second consisted of 421 registered nurses. This research found that perceived organizational support is positively associated with career satisfaction of older workers. Similarly, Cable and DeRue (2002), based on a longitudinal survey of 187 managerial employees of a telecommunication company in USA, found that perceived organizational support was significantly and positively related to career satisfaction. This study used the career satisfaction scale of Judge et al. (1995) to measure career satisfaction. Erdogan, Kraimer, and Liden (2004), based on a survey of 520 teachers from 30 high schools in Turkey, found that perceived organizational support was a significant predictor of career satisfaction. This study also used the career satisfaction scale of Greenhaus et al. (1990) to measure the career satisfaction of employees.

The studies reviewed above have operationalized "perceived organisational support" based on the definition from Einseberger et al. (1986), which states that perceived organizational support is the extent to which an organisation cares about employee wellbeing. Examples of the organizational support scale items developed by Eisenberger et al. (1986) are: "the organisation values my contribution to its wellbeing" and "the organization really cares about my wellbeing." None of these studies have reported on research that has explored how career oriented perceived organizational support/POS-Career (the extent to which organisations care specifically about employee career needs) is related to the career satisfaction. However, a recent study (Cao \& Deller, 2014) based on expatriate employees in Germany has found that career oriented perceived organizational support is significantly and positively related to the career satisfaction of employees. The perceived organizational support (POS) of this study was assessed with the POS questionnaire of Kraimer and Wayne (2004) which includes both "adjustment POS" (extent to which the organization cares about the employee's adjustment) and "career POS" (extent to which the organization cares about the employee's career needs). This study has employed the subjective career satisfaction (subjective career success) questionnaire developed by Greenhaus et al., (1990). Based on these theoretical justifications and empirical findings, it was hypothesised that the career oriented perceived organizational support (POS-Career) has a positive relationship with subjective career success of employees.

More recent studies also provide the empirical support for a positive relationship between perceived organizational support and subjective career satisfaction (Lee and Lee, 2019; Jung and Takeuchi, 2018; UlHussami et al., 2018; Joo \& Lee, 2017). For example, Jung and Takeuchi (2018), based on a sample of 364 Japanese employees, found that the employees were satisfied with their careers when they had higher perceived organizational support. A study conducted based on the 1627 Korean women managers, Lee and Lee (2019) revealed that the perceived organizational support is positively associated with subjective career satisfaction. Perceived organizational support of this study was operationalized in terms of supervisor support.

\section{Methodology}

\section{Sample and the data collection procedure}

The study was conducted in 15 large scale manufacturing firms in Sri Lanka. The selected firms consisted of a range of manufacturing firms which include consumer goods, ready to wear garments, agriculture and durable goods. A random sample of 10 supervisory level managers were selected from each firm to have a total sample of 150 managers. Human resource management department of each firm was contacted and web-links for an online survey was sent with the request of sending them to the selected sample of managers.

\section{Measures}

Career oriented perceived organisational support: To conduct this study, career oriented perceived organizational support was defined as the "extent to which the organization cares about its employees' career needs" (Kraimer \& Wayne, 2004, p. 218). A 5 item POSCareer scale was devised for this study by combining the POS-Career scale proposed by Kraimer et al. (2011) with some items in the perceived organizational support scale proposed by the Eisenberger et al. (2002) following some modifications to the original questions. The scale included items such as "my organization cares about my career development" and "my organization strongly considers my career goals when making career decisions." The scale was a five-point Likert scale which ranged from 'strongly agree' to strongly disagree.

Subjective career success: Subjective career success was operationally defined as the extent to which individuals believe that their career progress is consistent with their own goals, values and preferences (Erdogan et al., 2004; Heslin, 2003; Seibert \& Kraimer, 2001). Most prior 
studies have used the scale developed and validated by Greenhaus et al. (1990) to measure the subjective career success. This scale was used in this study. The scale included items such as: "I am satisfied with the success I have achieved in my career," and "I am satisfied with the progress I have made towards meeting my overall career goals." This scale was also a five-point Likert scale which ranged from "strongly agree" to "strongly disagree".

\section{Control Variables}

Respondents' demographic information such as age, gender, tenure and highest level of education completed were collected with single item questions.

\section{Results}

Only 88 respondents completed the survey which resulted in a response rate of 59\%. A Principal Component Analysis (PCA) was conducted only for the career oriented perceived organizational support scale since it has been devised solely for the purpose of this study which required validation. The results of KMO and Bartlett's Test are given in the Table-1. Since the KaiserMeyer-Olkin Measure of Sampling Adequacy (KMO) value is close to 1 , and the significance value is less than .05 , the sample is considered as adequate for the factor analysis. The total amount of variance accounted for in the construct by factors with eigenvalues above 1.0 was $72.98 \%$.

\section{Table 1: KMO and Bartlett's Test for POS-Career} Questionnaire

\begin{tabular}{lll}
\hline Kaiser-Meyer-0lkin Measure of Sampling Adequacy & \multicolumn{1}{c}{.946} \\
Bartlett's Test of Sphericity & Approx Chi Square & .8677 .612 \\
\cline { 2 - 3 } & $\mathrm{df}$ & 67 \\
\cline { 2 - 3 } & Sig & .000 \\
\hline
\end{tabular}

Source: Survey Data

\section{Results of the Factor Analysis}

The study employed the confirmatory factor analysis (CFA) by following the measures which were proposed by Hair et al., (2018):

- Visual inspection of correlations in the componet correlation matrix shows that the factors are interrelated to some degree. The fact that these correlations exist tell us that the constructs measured are interrelated.

- Bartlett's test of sphericity was used to test the presence of correlations among variables. A statistically significant Bartlett's test of sphericity (sig.<.05) indicates that sufficient correlations exist among variables. The overall measure of sampling adequacy (MSA) for the set of variables included in the analysis was 0.946 which exceeds the minimum requirement of 0.50 for overall MSA. Probability associated with Bartlett's Test of Sphericity was
$<0.001$ which was less than 0.05 . Therefore, the overall measure of sampling adequacy is acceptable.

Using a CFA with oblique rotation (Costello \& Osborne, 2005; Hair et al., 2018; Tabachnick \& Fidell, 2013), two factors with Eigenvalues greater than 1 were identified. The cummulative proportion of variance criteria met with two components to satisfy the criterion of explaining $60 \%$ or more of the total variance. A two components solution explained $66.71 \%$ of the total variance.

The communality value for each variable was higher than 0.50 . Consequently, all of the items were retained in the analysis, since factor solutions represent a significant proportion of variance in the original variables. As suggested by Hair et al. (2018) all loadings above \pm .40 were considered as factor loadings with practical significance. The strong conceptual foundation for the anticipated structure and its rationale provided the basis for interpretation of the factor structure (Hair et al., 2018). The factor solution is given in Table 2. The factors indicated in this table were named based on underlying conceptual dimensions and results from previous studies.

Table 2: Rotated Factor Loading Matrix

\begin{tabular}{lcc}
\hline \multicolumn{1}{c}{ Items } & POS- & CS \\
& C & \\
\hline $\begin{array}{l}\text { My organization values my career } \\
\text { progress }\end{array}$ & .767 & \\
My & &
\end{tabular}

My organization cares about my $\quad .805$

career development.

My organization strongly considers

my career goals when making career

decisions.

My organization keeps me informed

about available career development

opportunities

My organization has created a

conducive environment for me to

develop my career

I am satisfied with the success I have

achieved in my career.

I am satisfied with the progress I have

made towards meeting my overall career goals.

I am satisfied with the progress I have made towards achieving my income target.

I am satisfied with the progress I have made towards meeting my goals for career advancement.

I am satisfied with the progress I have made towards meeting my goals for the development of new skills.

\begin{tabular}{l}
\hline Notes: \\
Extraction Method: Principal Component Analysis \\
Rotation Method: Oblimin with Kaiser Normalization \\
Factor loadings $<.4$ are suppressed \\
POS-C= Career oriented perceived organizational \\
support \\
CS = Career Satisfaction \\
Source: Survey data
\end{tabular}


Means, standard deviations and inter-item correlations are shown in Table 3. The diagonal of this table presents Cronbach's Alpha values which indicate that all measures demonstrated adequate levels of reliability. Many managers were male $(65 \%)$. Mean and standard deviation statistics relating to these demographic variables are presented. The mean age of respondents was 44 and the average organizational tenure was 8 years. The inter-item correlation coefficients indicate that there are significant positive correlations between study variables.

Table 3: Correlation Matrix of Variables

\begin{tabular}{|c|c|c|c|c|c|c|}
\hline & Mean S.D. & 1 & 2 & 3 & 4 & 5 \\
\hline 1. Age (Years) & $44.0 \quad 8.9$ & & & & & \\
\hline 2. Gender & N/A NA & .173 & & & & \\
\hline 3. Tenure (Years) & $8 \quad 5.4$ & $.471^{* 8}$ & $.372 * *$ & & & \\
\hline 4. POS-Career & $3.97 \quad .44$ & -.343 & $-.161^{*}$ & $-.169^{8}$ & .991 & \\
\hline 5. Subjective Career Success & $3.26 \quad .82$ & $-.416^{* *}$ & $328 * *$ & $-.552^{* *}$ & $.675^{* *}$ & .877 \\
\hline
\end{tabular}

Notes: $* \mathrm{p}<0.05 ; * * \mathrm{p}<0.01$

Hypotheses Testing

The Multiple Hierarchical Regression Analysis was employed to test the proposed hypothesized relationships by controlling the effects of demographic variables such as age, gender, and tenure since correlation coefficients indicated that the demographic variables have significant relations with subjective career success. For example, as shown in Table 4, the demographic factors such as age ($416, \mathrm{p}<.01)$, gender $(.328, \mathrm{p}<.01)$ and tenure $(-.552$, $\mathrm{p}<.01)$ are correlated with the subjective career success. Table 4 presents the results of multiple hierarchical regression analysis.

This study hypothesized that the career oriented perceived support is positively related to the subjective career success. After controlling the effects of age, gender and tenure, the results indicated that the career oriented perceived organizational support is positively related to the subjective career success of employees $(\beta=$ $.598, \mathrm{p}<.05)$. Therefore, the hypothesized relationship proposed by this study is accepted.
Table 4: Hierarchical Regressions for POS-Career and Subjective Career Success Relationship

\begin{tabular}{lll}
\hline Predictors $($ Beta): & Step 1 & Step 2 \\
\hline Step 1: & \\
Age & $-.416^{*}$ & \\
Gender & $.328^{*}$ & \\
Tenure & $.552^{*}$
\end{tabular}

Step 2:

$\begin{array}{lll}\text { Age } & -.322^{*} \\ \text { Gender } & .339^{*} \\ \text { Tenure } & .472 * \\ \text { POS-Career } & & .598^{*} \\ \text { F Statistic } & 11.729 * & 16.925^{*} \\ \text { Adj. R-Sq. } & .164 * & .296^{*} \\ \text { R-Sq. Change } & .395 & .136\end{array}$

Note: $*=\mathrm{P}<.05$

\section{Discussion}

This study revealed that the POS-Career has a positive relationship with subjective career success of supervisory level managers of production firms in Sri Lanka. This finding implies that employees believe their career progress is consistent with their own goals, values, and preferences when they have developed a perception about the organization's caring of their career needs. The finding of the study provides implications to the Psychological Contract Theory (Argyris, 1960), Social Exchange Theory (Blau, 1964; Rosseau, 1989) and the Perceived Organizational Support Theory (Eisenberger et al., 1986). That is, employees' belief about the organization's caring of their career needs will build a reciprocal obligation in them and in turn they reciprocate with demonstrated career success. Based on the reciprocity norm, perceived organizational support produces a felt obligation in individuals to care about the organization's welfare and to help the organization reach its objectives (Eisenberger et al., 1986). Moreover, the findings provide implications to the Extended Model of Social Cognitive Career Theory (Lent and Brown, 2006) which states that the goal-specific environmental support, such as POS-Career, which provides for social support in achieving employee personal goals, is likely to be a predictor of their subjective career success.

An organization should develop a career development culture by providing employees with a range of career development opportunities, senior management's leadership for career development programs, and developing a climate for employees to involve in career self-management by engaging with networking and visibility behaviors. In response, they develop a belief that their career progress is consistent with their own goals, values, and preferences. Also, the employees would feel a reciprocal obligation (Rousseau, 
1989) towards the organization as a result of receiving these types of support. That is, motivationally focused organizational actions such as career oriented organizational support, will enhance employees' willingness to fully invest themselves physically, cognitively, and emotionally into their work roles (employee engagement) (Barrick et al., 2015). Overall, policy makers can learn from the study that they should build reciprocal obligations in employees by considering employee career goals in making career decisions and by regularly informing employees of all available career development opportunities within the organization so that the employees will have reasons to believe that the organization cares about their career needs. This felt obligation will lead employees to further their careers with the organization instead of engaging with externally oriented mobility behavior. Consequently, organizations may expect affective attachment and a felt obligation to stay with the organization. In terms of HR practices, If employees believe that the organization cares about their career needs and goals, the employees are likely to engage with career development activities and programs such as career training, provision of personal career development plans, provision of performance feedback by supervisors, career advice, provision of work that enhances skills for the future, and mentoring (Sturges et al., 2005; Sturges et al., 2000).

In spite of significant contributions of the study to the theory and practice of career development, it has some minor limitations. The selected sample of employees consisted mainly of supervisory level managers of manufacturing firms in Sri Lanka. Therefore, the study findings may to be generalizable to other managerial and non-managerial employee categories and other industries. Similarly, these outcomes may not be the case for different country contexts since prior studies have shown that there are differences between countries in terms of attitudes and behaviors (Kickul, Scott, \& Belgio, 2004; Yu \& Egri, 2005). Therefore, findings may not be generalized to other countries. The research was limited to a cross-sectional study. Therefore, as with all cross-sectional studies, no causality between variables is implied by this study.

Future studies could be conducted with a greater representation of different levels of employees in an organizational hierarchy to improve the generalizability of findings. In addition, to increase the generalizability, more studies in various industries representing diverse employee groups are needed. Moreover, similar studies should be conducted in other cultural contexts to further strengthen the knowledge in this research area. That is, some cross-cultural studies have identified differences between cultures in behavior and attitudes (Kickul et al., 2004; Yu \& Egri, 2005). Moreover, a qualitative study is worthwhile to provide further support for the findings of this study and to identify whether the found relationships are explained by national cultural dimensions. Furthermore, future studies could consider cultural factors such as beliefs, values and attitudes as moderating variables in the relationship between POS-Career and the subjective career success. The reason for the relationship between POS-Career and the subjective career success may be explained by the theory of Perceived Organizational Support (Eisenberger et al., 1986). Therefore, future studies could be conducted to investigate whether the perceived organizational support is a mediator of the relationship between POS-Career and the subjective career success.

\section{Conclusion}

By providing implications to the extended model of social cognitive career theory (Lent and Brown, 2006), perceived organizational support theory (Eisenberger et al., 1986), psychological contract theory (Argyris, 1960), and the social exchange theory (Blau, 1964), this study proposed that the employees believe their career progress is consistent with their own goals, values, and preferences when they have developed a perception about the organization's caring of their career needs. In addition to this theoretical contribution, the study made a methodological contribution by validating a career oriented perceived organizational support scale. Since there is a scant amount of literature that has investigated this relationship, this current study made a significant empirical contribution by conducting a study in a developing country context. The study proposes policy makers to develop a caring culture of career development by offering various career development programs for their employees.

\section{References}

Ahmed, I., Nawaz, M. M., Ali, G., \& Islam, T. (2015). Perceived organizational support and its outcomes: A meta-analysis of latest available literature. Management Research Review, 38(6), 627-639.

Allen, D.G., Shore, L. M., \& Griffeth, R. W. (2003). The role of perceived organizational supportand supportive human resource practices in the turnover process. Journal of Management, 29, 99-118.

Al-Hussami, M., Hammad, S., \& Alsoleihat, F. (2018). The influence of leadership behavior, organizational commitment, organizational support, subjective career success on organizational readiness for change in healthcare organizations. Leadership in Health Services.

Argyris, C. P. (1960). Personality and organization. Hospital Administration, 5(1), 6-32.

Armstrong-Stassen, M., \& Ursel, N.D. (2009). Perceived organizational support, career satisfaction, and retention of older workers. Journal of Occupational and Organizational Psychology, 82, 201-220.

Arthur, M. B., Khapova, S. N., \& Wilderom, C. P. M. (2005). Career success in a boundaryless career world. Journal of Organizational Behavior, 26, 177-202.

Bambacas, M., \& Bordia, P. (2009). Predicting different commitment components: the relative effects of how career development HRM practices are perceived. Journal of Management \& Organization, 15, 224-240. 
Barnett, B.R., \& Bradley, L. (2007). The impact of organisational support for career development on career satisfaction. Career Development International, 12(7), 617-636.

Barrick, M. R., Thurgood, G. R., Smith, T. A., \& Courtright, S. H. (2015). Collective organizational engagement: Linking motivational antecedents, strategic implementation, and firm performance. Academy of Management Journal, 58(1), 111135 .

Baruch, Y. (1999). Integrated career systems for the 2000s. International Journal of Manpower, 20(7), 432-457.

Blau, P. (1964). Exchange and power in social life.New York: John Wiley.

Burke, L. A. , \& Hutchins, H. M. (2007). Training transfer: An integrative literature review. Human Resource Development Review, 6, 263-296.

Cable, D.M., \& DeRue, D.S. (2002). The convergence and discriminant validity of subjective fit perceptions Journal of Applied Psychology, 87, 875-884

Cao, L., Hirschi, A., \& Deller, J. (2014). The positive effects of a protean career attitude for selfinitiated expatriates: Cultural adjustment as a mediator. Career Development International, 18(1), 56-77.

DeVos, A., Dewettinck, K., \& Buyens, D. (2009). The professional career on the right track: A study on the interaction between career selfmanagement and organizational career management in explaining employee outcomes. European Journal of Work and Organizational Psychology, 18(1), 55-80.

Dubin, S. S. (1977). A learning model for updating older technical and professional persons. Paper presented at the annual meeting of the American Psychological Association. San Francisco, CA.

Eby, L. T., Allen, T. D., \& Brinley, A. (2005). A crosslevel investigation of the relationship between career management practices and career-related attitudes. Group and Organization Management, 30(6), 565-596.

Eisenberger, R., Huntington, R., Hutchison, S., \& Sowa, D. (1986). Perceived organizational support. Journal of Applied Psychology, 71, 500-507.

Eisenberger, R., Stinglhamber, F., Vandenberghe, C., Sucharski, I, \& Rhoades, L. (2002). Perceived supervisor support : Contributions to perceived organizational support and employee retention. Journal of Applied Psychology, 87, 565-573.
Erdogan, B., Kraimer, M.L., \& Liden, R.C. (2004). Work value congruence and intrinsic career success: the compensatory roles of leader-member exchange and perceived organizational support. Personnel Psychology, 57(2), 305-332.

Greenhaus, J.H., parasuraman, S., \& Wormley, W. (1990). Effects of race on organizational experiences, job performance evaluations, and career outcomes. Academy of Management Journal, 33(1), 64-86.

Hair, J.F., Black, W.C., Babin, B.J., \& Anderson, R.L., (2018). Multivariate data analysis, $8^{\text {th }} e d$. New Jersey: Prentice-Hall.

Heslin, P.A. (2003). Self- and other-referent criteria of career success. Journal of Career Assessment, 11(3), 262-286.

Joo, B. K., \& Lee, I. (2017, August). Workplace happiness: Work engagement, career satisfaction, and subjective well-being. In Evidence-based HRM: A Global Forum for Empirical Scholarship. Emerald Publishing Limited.

Judge, T.A., Cable, D.M., Boudreau, J.W., \& Bretz, R.D. (1995). An empirical investigation of the predictors of executive career success. Personnel Psychology, 48(3), 485-519.

Jung, Y., \& Takeuchi, N. (2018). A lifespan perspective for understanding career self-management and satisfaction: The role of developmental human resource practices and organizational support. Human Relations, 71(1), 73-102.

Karatepe, O.M. (2012). Perceived organisational support, career satisfaction, and performance outcomes. International Journal of Contemporary Hospitality Management, 24(5), 735-752.

Kaufman, H. G. (1974). Obsolescence and professional career development. New York, NY: Amacom.

Kickul, J., Scott, W., \& Belgio, E. (2004). Attitudinal and behavioral outcomes of psychological contract breach: A cross cultural comparision of the United States and Hong Kong Chinese. International Journal of Cross Cultural Management, 4(2), 229-252.

Kozlowski, S. W., \& Hults, B. M. (1987). An exploration of climates for technical updating and performance. Personnel Psychology, 40, 539563.

Kraimer, M. L., \&Wayne, S. J. (2004). An examination of perceived organizational support as a multidimensional construct in the context of an expatriate assignment. Journal of Management, 30, 209-237. 
Kraimer, M.L., Seibert, S.E., Wayne, S.J. , Liden, R.C., \& Bravo, J. (2011). Antecedents and outcomes of organizational support for development: the critical role of career opportunities. Journal of Applied Psychology, 96(3), 485-500.

Kurtessis, J. N., Eisenberger, R., Ford, M. T., Buffardi, L. C., Stewart, K. A., \& Adis, C. S. (2017). Perceived organizational support: A metaanalytic evaluation of organizational support theory. Journal of Management, 43(6), 18541884.

Lee, Y., \& Lee, J. Y. (2019). Mediating effects of the meaningfulness of work between organizational support and subjective career success. International Journal for Educational and Vocational Guidance, 19(1), 151-172.

Lent, R.W., \& Brown, S.D. (2006). Integrating person and situation perspectives on work satisfaction: A social-cognitive view. Journal of Vocational Behavior, 69(2), 236247. https://doi.org/10.1016/j.jvb.2006.02.006

Ng, T.W.H., Eby, L.T., Sorensen, K.L. , \& Feldman, D.C. (2005). Predictors of objective and subjective career success: a meta-analysis. Personnel Psychology, 58, 367-408.

Orpen, C. (1994). The effects of organizational and individual career management on career success. International Journal of Manpower, 15(1), 27-37.

Rhoades, L., \& Eisenberger, R. (2002). Perceived organizational support: A review of the literature. Journal of Applied Psychology, 87, 698-714.

Rousseau , D. (1995). Psychological contracts in organizations: Thousand Oaks, CA:Sage.

Rousseau , D. M. (1989). Psychological and implied contracts in organizations Employee Responsibilities and Rights Journal 2, 121-139.

Seibert, S.E., \& Kraimer, M.L. (2001). The five-factor model of personality and career success. Journal of Vocational Behavior, 58(1), 121. https://doi.org/10.1006/jvbe.2000.1757

Stickland, R. (1996). Career self-management-can we live without it? . European Journal of Work and Organizational Psychology, 5, 583-596.

Sturges, J., Conway, N., Guest, D., \& Liefooghe, A. (2005). Managing the career deal: The psychological contract as a framework for understanding career management, organizational commitment and work behavior.Journal of Organizational Behavior, 26, 821-838.
Sturges, J., Guest, D., \& Mackenzie Davey, K. (2000). Who is in charge? graduates attitudes to and experiences of career management and their relationship with organizational commitment. European Journal of Work and Organizational Psychology, 9(3), 351-370.

Sullivan, S. E. (1999). The changing nature of careers: A review and research agenda. Journal of Management,, 25(3), 457-484.

Susskind, A.M., Borchgrevink, C.P., Kacmar, K.M., \& Brymer, R.A. (2000). Customer service employees'behavirol intentions and attitudes: an examination of construct validity and path model. International Journal of Hospitality Management, 19(1), 53-77.

Yu, B.B., \& Egri, C.P. (2005). Human resource management practices and affective organizational commitment: A comparision of Chinese employees in a state-owned enterprise and a joint venture Asia Pacific Journal of Human Resources, 43(3), 332-360. 